\title{
Terbutaline in children with asthma
}

\author{
JENS LEEGAARD` and SVERRE FJULSRUD $\dagger$ \\ From the Department of Paediatrics, Allergy Section, Rikshospitalet, Oslo, Norway
}

Leegaard, J., and Fjulsrud, S. (1973). Archives of Disease in Childhood, 48, 229. Terbutaline in children with asthma. A double-blind, single-dose trial was carried out on 30 asthmatic children to study the effect of oral terbutaline in two different concentrations and of a placebo on ventilatory function and pulse rate. The higher dose of terbutaline $(0.075 \mathrm{mg} / \mathrm{kg})$ gave a satisfactory and prolonged action on ventilation without cardiovascular side effects.

Sympathomimetic amines have an established place in the treatment of bronchial asthma. Since the introduction of isoprenaline, a search has been undertaken for compounds with a more prolonged broncholytic action combined with fewer cardiovascular side effects. Orciprenaline was a successful result of this search (Engelhardt, Hoefke, and Wick, 1961).

Lands, Groblewski, and Brown showed in 1966, and Lands et al. in 1967, that there were two distinct receptors of the $\beta$-adrenergic type; the optimal structural requirements for cardiac stimulation were different from those for the advantageous broncholytic activity. After this differentiation, salbutamol was introduced, having more $\beta_{2}$ - and less $\beta_{1}$-stimulating properties than previously known catecholamines (Hartley et al., 1968; Brittain et al., 1968), and about the same time terbutaline was investigated by Bergman, Persson, and Wetterlin (1969).

Terbutaline differs chemically from orciprenaline in that the $\mathrm{N}$-isopropyl group is replaced by an $\mathrm{N}$-tertiary butyl group. This change makes dealkylation more difficult and enhances the $\beta$-receptor stimulating properties of terbutaline.

Animal experiments have shown that terbutaline acts selectively on bronchial muscle, with little or no effect on cardiac musculature (Persson and Olsson, 1970). Clinical trials in adults (Arner, 1970; Formgren, 1970a, b; Freedman, 1971) have confirmed the pronounced and long-lasting broncholytic activity and the negligible cardiovascular side effects.

The purpose of this paper is to report a study

Received 5 July 1972.

$\star$ Present address: Department of Paediatrics, Aalesund Hospital, 6000 Aalesund, Norway.

Present address: Tomtebo Home for Asthmatic Children, 3370 Vikersund, Norway. of the broncholytic effect and cardiovascular side effects of terbutaline, given as a single dose and in different concentrations, in asthmatic children.

\section{Materials and methods}

Patients. 10 girls and 20 boys ranging in age from 5 to 13, all suffering from moderately severe or severe bronchial asthma with symptoms from 4 to 11 years, were studied. All were in hospital because of the severity of the disease.

To be accepted into the trial a patient's peak expiratory flow rate, measured each morning of the trial, was $70 \%$ or less of the predicted normal value based on age, sex, and height (Dugdale and Moeri, 1968; Godfrey, Kamburoff, and Nairn, 1970).

At the time of the trial 4 children were receiving steroids and 3 disodium cromoglycate. All bronchodilator drugs and disodium cromoglycate were stopped 12 hours before the trial was carried out. Children receiving steroids or antibiotics continued this treatment throughout the trial period in unchanged doses.

The trial was carried out as a double-blind study on three consecutive days, a single dose of placebo and two different doses of terbutaline being given orally on separate days. One dose of terbutaline corresponded to the adult dose $(0.075 \mathrm{mg} / \mathrm{kg})$, the other dose being half this $(0.0375 \mathrm{mg} / \mathrm{kg})$. Terbutaline and placebo were administered in equal volumes as a syrup with identical smell, taste, and colour. The order in which the children received the various solutions was randomized according to the principle of Latin squares.

Respiratory function tests. Measurements were made of the peak expiratory flow rate (PEFR) using a Wright's Peak Flow Meter (Wright and McKerrow, 1959). $\ddagger$

The children were all well acquainted with the technique of PEFR measurements from previous hospital stays. On the day of the trial they rested for at least 5 minutes and then three resting PEFR readings were

‡Airmed Ltd., Harlow, Essex, England. 


\begin{tabular}{|c|c|c|c|c|c|c|}
\hline & \multicolumn{2}{|c|}{ Initial value } & \multicolumn{4}{|c|}{ Difference after $1 \mathrm{hr}$} \\
\hline & No. & $\mathbf{M}$ & No. & $\mathbf{M}$ & \pm SEM & $t_{0} \overline{\bar{\omega}}$ \\
\hline $\begin{array}{l}\text { Terbutaline } 0.075 \mathrm{mg} / \mathrm{kg} \text { (A) } \\
\text { Terbutaline } 0.0375 \mathrm{mg} / \mathrm{kg} \text { (B) } \\
\text { Placebo (C) } \\
\text { Difference between difference } \\
\text { Dose A/dose C } \\
\text { Dose B/dose C } \\
\text { Dose A/dose B }\end{array}$ & $\begin{array}{l}24 \\
27 \\
26\end{array}$ & $\begin{array}{l}162 \\
158 \\
153\end{array}$ & $\begin{array}{l}24 \\
27 \\
26 \\
23 \\
25 \\
24\end{array}$ & $\begin{array}{r}+38 \cdot 8 \\
+14 \cdot 3 \\
+3 \cdot 7\end{array}$ & $\begin{array}{l}5 \cdot 88 \\
4 \cdot 70 \\
3 \cdot 74\end{array}$ & 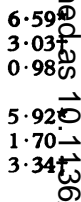 \\
\hline
\end{tabular}

No., number of patients; $M$, mean of individual changes from initial value; $S E M$, standard error of the mean; $t_{0}$, difference between the क्ञ⿰氵

recorded. The solution was given and PEFR measurements were made at $1,2,3$, and 5 hours. On each occasion three PEFR values were obtained and the highest value recorded.

Pulse rate. The pulse rate was measured by palpation of the radial artery for 1 minute immediately before each PEFR measurement.

Side effects. Notes were taken of any spontaneous remarks by the children relating to their symptoms after taking the solutions. After 5 hours the children were asked if they had noticed any symptoms such as tremor, palpitation, headache, or sweating.

Statistics. Student's ' $t$ ' test (Mainland, 1963; Snedecor and Cochran, 1967) was used for evaluation of the results, the degree of significance being given as significant $(P<0.01)$, or highly significant $(P<0.001)$.

\section{Results}

Airway obstruction. The lower dose of terbutaline had a significant effect after 1 hour, and a highly significant effect after 2 and 3 hours (Table I, Fig. 1). The effect after the higher dose was highly significant after the first 3 hours, and significant after 5 hours (Table I, Fig. 1.)

The difference in effect between the high dose of terbutaline and placebo was highly significant after the first 3 hours, and significant after 5 hours. Between the lower dose and placebo the difference was highly significant after 3 hours. Between the two doses of terbutaline the difference was significant after 1 and 2 hours (Table I).

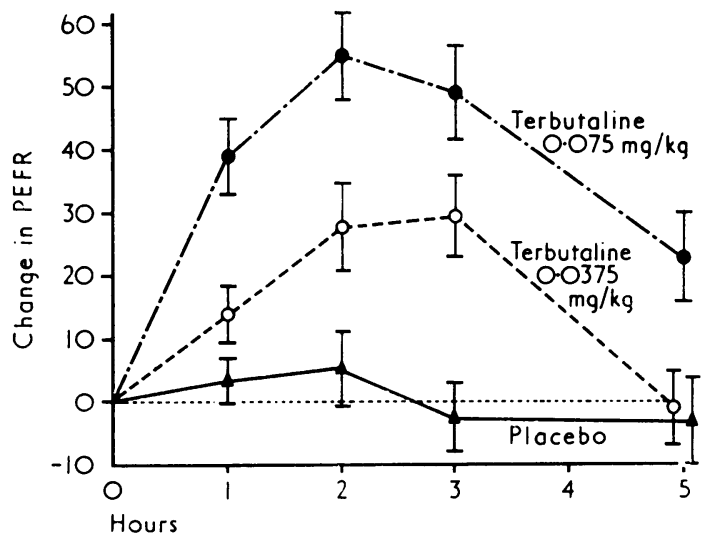

FIG. 1.-Mean of individual changes in peak expiratory flow rate from the initial value after oral administration of two doses of terbutaline and placebo. Bars represent $\pm 1 S D$.

\begin{tabular}{|c|c|c|c|c|c|c|}
\hline & \multicolumn{3}{|c|}{ Initial value } & \multicolumn{3}{|c|}{ Difference after $1 \mathrm{hr}$} \\
\hline & No. & $\mathbf{M}$ & No. & $\mathbf{M} \pm$ & SEM & $t_{0} \omega \sigma$ \\
\hline
\end{tabular}

No., number of patients; $M$, mean of individual changes from initial value; SEM, standard error of the mean; $t_{0}$, difference between the $\overrightarrow{\mathbb{R}^{2}}$ 
ite (l./min)

\begin{tabular}{|c|c|c|c|c|c|c|c|c|c|c|c|}
\hline $\begin{array}{l}24 \\
27 \\
26\end{array}$ & $\begin{array}{r}+55.0 \\
+27.6 \\
+5.6\end{array}$ & $\begin{array}{l}7 \cdot 01 \\
7 \cdot 14 \\
6 \cdot 21\end{array}$ & $\begin{array}{l}7 \cdot 84^{\star} \\
3 \cdot 87^{\star} \\
0 \cdot 89\end{array}$ & $\begin{array}{l}24 \\
27 \\
26\end{array}$ & $\begin{array}{r}+49.0 \\
+29.6 \\
-2.3\end{array}$ & $\begin{array}{l}7 \cdot 48 \\
6 \cdot 31 \\
6 \cdot 09\end{array}$ & $\begin{array}{l}6 \cdot 55^{\star} \\
4 \cdot 70^{\star} \\
0 \cdot 38\end{array}$ & $\begin{array}{l}21 \\
24 \\
25\end{array}$ & $\begin{array}{r}+23 \cdot 1 \\
-0 \cdot 8 \\
-3 \cdot 0\end{array}$ & $\begin{array}{l}6 \cdot 98 \\
6 \cdot 25 \\
7 \cdot 10\end{array}$ & $\begin{array}{l}3 \cdot 31 \dagger \\
0 \cdot 13 \\
0 \cdot 42\end{array}$ \\
\hline $\begin{array}{l}23 \\
25 \\
24\end{array}$ & & & $\begin{array}{l}6 \cdot 08^{\star} \\
2 \cdot 78 \\
3 \cdot 33 t\end{array}$ & $\begin{array}{l}23 \\
25 \\
24\end{array}$ & & & $\begin{array}{l}6 \cdot 47^{\star} \\
4 \cdot 34^{\star} \\
2 \cdot 33\end{array}$ & $\begin{array}{l}19 \\
21 \\
20\end{array}$ & & & $\begin{array}{l}3 \cdot 87 \dagger \\
0.59 \\
2 \cdot 50\end{array}$ \\
\hline
\end{tabular}

Pulse rate. The rise in pulse rate was almost significant after 2 hours using the high dose of terbutaline. Otherwise there were no changes in pulse rate at any time using any of the solutions (Table II, Fig. 2).

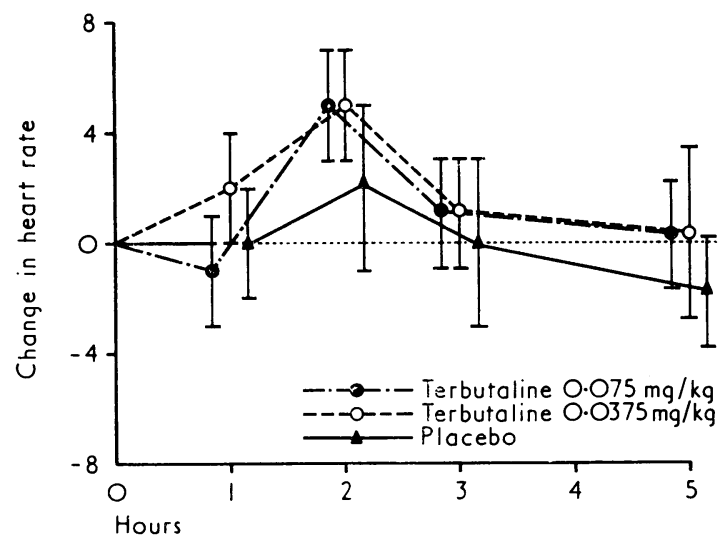

Fig. 2.-Mean of individual changes in heart rate from the initial value after oral administration of two doses of terbutaline and placebo. Bars represent $\pm 1 S D$.
Side effects. No side effects were noted at any time during or after the trial.

\section{Discussion}

The results show that orally administered terbutaline in the concentrations used produces marked bronchodilatation in asthmatic children for a period of at least 5 hours without tachycardia.

The mean maximal PEFR increase after the lower dose of terbutaline was no better than $60 \%$ of the increase after the high dose at any time. Table I shows that this difference in effect was significant for the first 2 hours. This ventilatory advantage indicates that the high dose (which corresponds to the adult dose) is to be preferred to the lower when given as a single dose.

The observed changes in heart rate show that the higher dose exerts some activity on the $\beta_{1}$-receptors. The mean maximal increase was 5 beats per minute after the higher dose. This corresponds well with the results of investigations in adults (Formgren, 1970a), but is in contrast to that of Freedman (1971) who found a much higher heart rate increase.

It is possible that an even greater degree of eats/min)

\begin{tabular}{|c|c|c|c|c|c|c|c|c|c|c|c|}
\hline \multicolumn{4}{|c|}{ Difference after $2 \mathrm{hr}$} & \multicolumn{4}{|c|}{ Difference after $3 \mathrm{hr}$} & \multicolumn{4}{|c|}{ Difference after $5 \mathrm{hr}$} \\
\hline No. & $M \pm$ & SEM & $t_{0}$ & No. & $M \pm$ & SEM & $t_{0}$ & No. & $\mathbf{M} \pm$ & SEM & $t_{0}$ \\
\hline $\begin{array}{l}29 \\
30 \\
30 \\
\\
29 \\
30 \\
29\end{array}$ & $\begin{array}{l}+5 \cdot 0 \\
+4 \cdot 5 \\
+1 \cdot 6\end{array}$ & $\begin{array}{l}2 \cdot 10 \\
2 \cdot 30 \\
2 \cdot 53\end{array}$ & $\begin{array}{l}2.37 \\
1.94 \\
0.66 \\
0.97 \\
0.80 \\
0.12\end{array}$ & $\begin{array}{l}29 \\
30 \\
30 \\
\\
29 \\
30 \\
29\end{array}$ & $\begin{array}{r}+1.3 \\
+1.4 \\
-0.3\end{array}$ & $\begin{array}{l}2 \cdot 21 \\
2 \cdot 30 \\
2 \cdot 74\end{array}$ & $\begin{array}{l}0.59 \\
0.64 \\
0.12 \\
0.28 \\
0.49 \\
0.07\end{array}$ & $\begin{array}{l}26 \\
28 \\
29 \\
\\
25 \\
27 \\
26\end{array}$ & $\begin{array}{r} \pm 0.0 \\
+0.4 \\
-2.1\end{array}$ & $\begin{array}{l}2 \cdot 10 \\
2 \cdot 58 \\
2 \cdot 15\end{array}$ & $\begin{array}{l}0.00 \\
0.14 \\
0.96 \\
0.91 \\
0.82 \\
0.39\end{array}$ \\
\hline
\end{tabular}


bronchodilatation could have been achieved using a higher concentration of terbutaline, but probably at the cost of some tachycardia.

In conclusion, the ventilatory benefits combined with no cardiovascular side effects makes terbutaline a safe and effective broncholytic agent when given as a single dose and in a concentration of $0.075 \mathrm{mg} / \mathrm{kg}$ body weight.

W'e thank Dr. K. Aas for permission to investigate patients under his care and for his advice concerning the trial and preparing the manuscript; nurses Anne Kasin and Valborg Lachman-Mørch for technical assistance; and DRACO AB for supplying the samples and carrying out the statistical analyses.

\section{REFERENCES}

Arner, B. (1970). A comparative clinical trial of different subcutaneous doses of terbutaline and orciprenaline in bronchial asthma. Acta Medica Scandinavica, Suppl. 512, 45.

Bergman, J., Persson, H., and Wetterlin, K. (1969). Two new groups of selective stimulants of adrenergic $\beta$-receptors. Experientia, 25, 899.

Brittain, R. T., Farmer, J. B., Jack, D., Martin, L. E., and Simpson, W. T. (1968). $\alpha$-[(t-butylamino)methyl]-4-hydroxy-m-xylene$\alpha^{1}, \alpha^{3}$-diol (AH.3365): a selective $\beta$-adrenergic stimulant. Nature (London), 219, 862.

Dugdale, A. E., and Moeri, M. (1968). Normal values of forced vital capacity (FVC), forced expiratory volume $\left(F E V_{1.0}\right)$ and peak flow rate (PFR) in children. Archives of Disease in Childhood, 43, 229.

Engelhardt, A., Hoef ke, W., and Wick, H. (1961). Pharmacology of the sympathomimetic amine drug 1-(3,5-Dihydroxyphenyl)1-hydroxy-2-isopropylaminoethane. Arzneimittel-Forschung, 11,521 .
Formgren, H. (1970a). A clinical comparison of the effect of oral terbutalin and orciprenaline. Scandinavian fournal of Respiratory Diseases, 51, 195.

Formgren, H. (1970b). Clinical comparison of inhaled terbutaline and orciprenaline in asthmatic patients. Scandinavian fournal of Respiratory Diseuses, 51, 203.

Freedman, B. J. (1971). Trial of new bronchodilator, terbutaline, in asthma. British Medical fournal, 1, 633.

Godfrey, S., Kamburoff, P. L., and Nairn, J. R. (1970). Spirometry, lung volumes and airway resistance in normal children aged 5 to 18 years. British Fournal of Diseases of the Chest, 64, 15.

Hartley, D., Jack, D., Lunts, L. H. C., and Ritchie, A. C. (1968). New class of selective stimulants of $\beta$-adrenergic receptors. Nature (London), 219, 861.

Lands, A. M., Groblewski, G. E., and Brown, T. G., Jr. (1966). Comparison of the action of isoproterewol and several related compounds on blood pressure, heart and bronchioles. Archives Internationales de Pharmacodynamie et de Thérapie, 161, 68.

Lands, A. M., Arnold, A., McAuliff, J. P., Luduena, F. P., and Brown, T. G., Jr. (1967). Differentiation of receptor systems activated by sympathomimetic amines. Nature (London), 214, 597.

Mainland, D. (1963). Elementary Medical Statistics, 2nd ed., p. 290. Saunders, Philadelphia.

Persson, H., and Olsson, T. (1970). Some pharmacological properties of terbutaline (INN),1-(3,5-dihydroxyphenyl)-2(T-butylamino-ethanol). A new sympathomimetic $\beta$-receptor stimulating agent. Acta Medica Scandinavica, Suppl. 512, 11.

Snedecor, G. W., and Cochran, W. G. (1967). Statistical Methods, 6th ed., p. 59. Iowa State University Press, Ames.

Wright, B. M., and McKerrow, C. B. (1959). Maximum forced expiratory flow rate as a measure of ventilatory capacity. With a description of a new portable instrument for measuring it. British Medical fournal, 2, 1041.

Correspondence to Dr. J. Leegaard, Department of Paediatrics, Aalesund Hospital, 6000 Aalesund, Norway. 